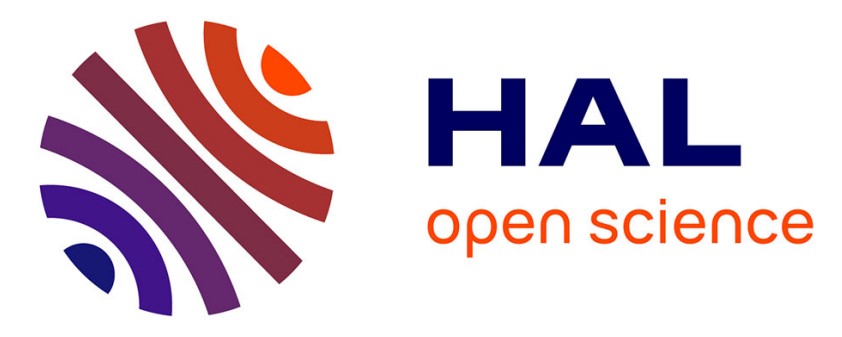

\title{
Study of Local Structures of Ni-Mn Alloys by EXAFS
}

\author{
M. Nakahata, M. Yuza, Y. Kondo, T. Miyanaga, T. Okazaki
}

\section{To cite this version:}

M. Nakahata, M. Yuza, Y. Kondo, T. Miyanaga, T. Okazaki. Study of Local Structures of NiMn Alloys by EXAFS. Journal de Physique IV Proceedings, 1997, 7 (C2), pp.C2-1185-C2-1186. 10.1051/jp4:19972185 . jpa-00255254

\section{HAL Id: jpa-00255254 https://hal.science/jpa-00255254}

Submitted on 1 Jan 1997

HAL is a multi-disciplinary open access archive for the deposit and dissemination of scientific research documents, whether they are published or not. The documents may come from teaching and research institutions in France or abroad, or from public or private research centers.
L'archive ouverte pluridisciplinaire HAL, est destinée au dépôt et à la diffusion de documents scientifiques de niveau recherche, publiés ou non, émanant des établissements d'enseignement et de recherche français ou étrangers, des laboratoires publics ou privés. 


\title{
Study of Local Structures of Ni-Mn Alloys by EXAFS
}

\author{
M. Nakahata, M. Yuza, Y. Kondo, T. Miyanaga and T. Okazaki \\ Department of Physics, Faculty of Science, Hirosaki University, Hirosaki, Aomori 036, Japan
}

\begin{abstract}
EXAFS spectra of NiMn alloys annealed at various conditions have been measured at Ni and $\mathrm{Mn} K$-edges. A simple method to estimate the degree of short-range order of atomic arrangements in NiMn alloys is presented. It is found that the short range order in NiMn obtained from EXAFS corresponds to the magnetic properties.
\end{abstract}

\section{INTRODUCTION}

NiMn alloys exhibit characteristic magnetic behavior depending on the concentration of Mn and the conditions of heat treatments. Recently, the differences of the magnetic properties between $\mathrm{Ni}_{0.75} \mathrm{Mn}_{0.25}$ and $\mathrm{Ni}_{0.80} \mathrm{Mn}_{0.20}$ have been studied by Okazaki[1]. It has been shown that: (1) $\mathrm{Ni}_{0.75} \mathrm{Mn}_{0.25}$ represents a double-stage behavior in the magnetization- $v s$-temperature curve at the lower state of order, however $\mathrm{Ni}_{0.80} \mathrm{Mn}_{0.20}$ does not show such a behavior; (2) the Curie temperature of $\mathrm{Ni}_{0.75} \mathrm{Mn}_{0.25}$ is higher than that of $\mathrm{Ni}_{0.80} \mathrm{Mn}_{0.20}$; (3) the saturation magnetization of $\mathrm{Ni}_{0.75} \mathrm{Mn}_{0.25}$ is larger than that of $\mathrm{Ni}_{0.80} \mathrm{Mn}_{0.20}$.

In order to study such differences in the magnetic properties between $\mathrm{Ni}_{0.75} \mathrm{Mn}_{0.25}$ and $\mathrm{Ni}_{0.80} \mathrm{Mn}_{0.20}$ alloys from the view point of the local structures and short-range order, we carried out the EXAFS analyses of Ni and Mn $K$-edges for these alloys.

\section{EXPERIMENTAL}

The $K$-edge absorption spectra for $\mathrm{Ni}$ and $\mathrm{Mn}$ were recorded in transmission mode at BL $7 \mathrm{C}$ at Photon Factory in Tsukuba. A $\mathrm{Si}(111)$ double crystal monochromator was used. The storage ring was operated at $2.5 \mathrm{GeV}$ and the ring current was $200-$ $300 \mathrm{~mA}$. All samples were ground to fine powder (the grain size is smaller than $38 \mu \mathrm{m}$ ). $\mathrm{Ni}_{0.75} \mathrm{Mn}_{0.25}$ alloys were annealed at $400^{\circ} \mathrm{C}$ for 25 hours, 200 hours and 1000 hours and $\mathrm{Ni}_{0.80} \mathrm{Mn}_{0.20}$ were annealed at the same temperature for 10 hours and 200 hours.
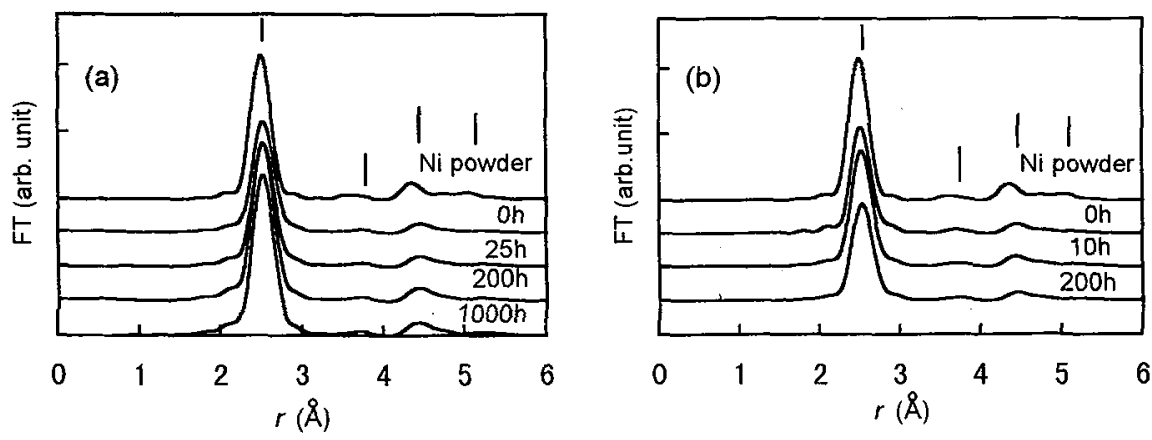

Figure 1. Fourier transforms of $\mathrm{Ni} K$-edge EXAFS for various annealing times; (a) $\mathrm{Ni}_{0.75} \mathrm{Mn}_{0.25}$ and (b) $\mathrm{Ni}_{0.80} \mathrm{Mn}_{0.20}$. Vertical lines show the positions of surrounding atoms.

\section{RESULTS AND DISCUSSION}

The FT of Ni $K$-edge EXAFS for NiMn alloys which are annealed at various time are shown in Fig. 1 . The spectra were analyzed in the same method described previously[2]. The FT of Ni powder is also shown in Figure1 for comparison. First peak in Fig. 1 corresponds to the interatomic distances of $\mathrm{Ni}-\mathrm{Ni}$ or $\mathrm{Ni}-\mathrm{Mn}$. The peak positions for $\mathrm{Ni}_{0.75} \mathrm{Mn}_{0.25}$ (a) shift to shorter $r$ with increasing annealing time and approach to the FT of Ni powder. Unfortunately, these two kind of distances can 
not be separated by EXAFS technique. We carry out one-shell curve-fitting for both spectra. The distance for first nearest atoms is $2.53 \AA$ for $\mathrm{Ni}_{0.75} \mathrm{Mn}_{0.25}$ and $2.52 \AA$ for $\mathrm{Ni}_{0.80} \mathrm{Mn}_{0.20}$. These results correspond to the X-ray diffraction results[3]. Figure 2 shows the first peak intensities of FT of $N i K$-edge(a), $I_{N i-K}$, and that of $M n K$-edge (b), $I_{M n-K}$, as a function of annealing time. The peak intensities of $\mathrm{FT}$ for $\mathrm{Ni}_{0.75} \mathrm{Mn}_{0.25}$ increase with annealing time, whereas that for $\mathrm{Ni}_{0.80} \mathrm{Mn}_{0.20}$ decrease at 200 hours.
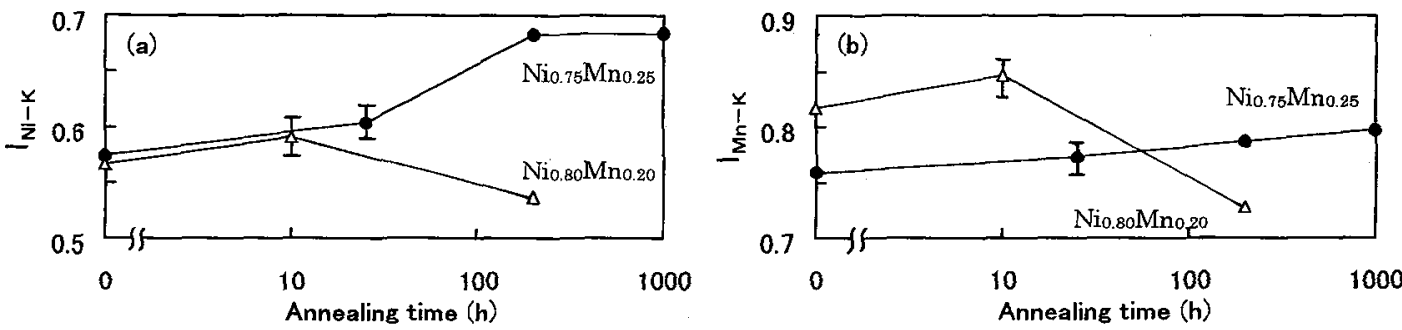

Figure 2. The peak intensities of FT for NiMn alloys as a function of annealing time for (a) Ni $K$-edge and (b) Mn $K$-edge. Lines are drawn as guides for eye.

Generally, the peak intensity of FT for EXAFS is affected by the type of photoelectron backscattering atom and a distortion of local structure. In order to extract the information about the degree of short range order from the EXAFS, we introduce the ratio, $P$, between $\mathrm{I}_{\mathrm{Ni}-\mathrm{K}}$ and $\mathrm{I}_{\mathrm{Mn}-\mathrm{K}}$ according to well-known EXAFS formula,

$$
P=\frac{\mathrm{I}_{\mathrm{Ni}-\mathrm{K}}}{\mathrm{I}_{\mathrm{Mn}-\mathrm{K}}}=\frac{\left\{x \mathrm{~F}_{\mathrm{Ni}}+(1-x) \mathrm{F}_{\mathrm{Mn}}\right\} \exp \left(-2 \sigma_{\mathrm{Ni}}{ }^{2} k^{2}\right)}{\left\{y \mathrm{~F}_{\mathrm{Ni}}+(1-y) \mathrm{F}_{\mathrm{Mn}}\right\} \exp \left(-2 \sigma_{\mathrm{Mn}^{2}}{ }^{2}\right)},
$$

where $x$ is the proportion of $\mathrm{Ni}$ atoms around $\mathrm{Ni}$ and $y$ is that around $\mathrm{Mn}$ atom. $\mathrm{F}_{\mathrm{Ni}}$ and $\mathrm{F}_{\mathrm{Mn}}$ is the backscattering amplitude of $\mathrm{Ni}$ and $\mathrm{Mn}$ atoms, respectively. If we assume that the distortions of local structures around $\mathrm{Ni}$ is equal to that around $\mathrm{Mn}$, $P$ represents the degree of short range order of NiMn alloys; that is, the larger the $P$ value is, the higher the degree of order is. Figure 3 shows the relative $P$ value obtained from the results in Fig. 2, where $P$ of quench states is set to be 1.0 . We found interesting phenomenon that the increment of $P$ with anunealing time for $\mathrm{Ni}_{0.75} \mathrm{Mn}_{0.25}$ is twice as large as that for $\mathrm{Ni}_{0.80} \mathrm{Mn}_{0.20}$. It is known that the saturation magnetization is affected by the short range order of the atomic arrangement in NiMn alloy. The present EXAFS result indicates that $\mathrm{Ni}_{0.75} \mathrm{Mn}_{0.25}$ alloy with higher short-range order represents a higher saturation magnetization $\left(713 \times 10^{-4} \mathrm{~T}\right)$ and $\mathrm{Ni}_{0.80} \mathrm{Mn}_{0.20}$ with lower short-range order shows a lower saturation magnetization $\left(483 \times 10^{-4} \mathrm{~T}\right)[1]$
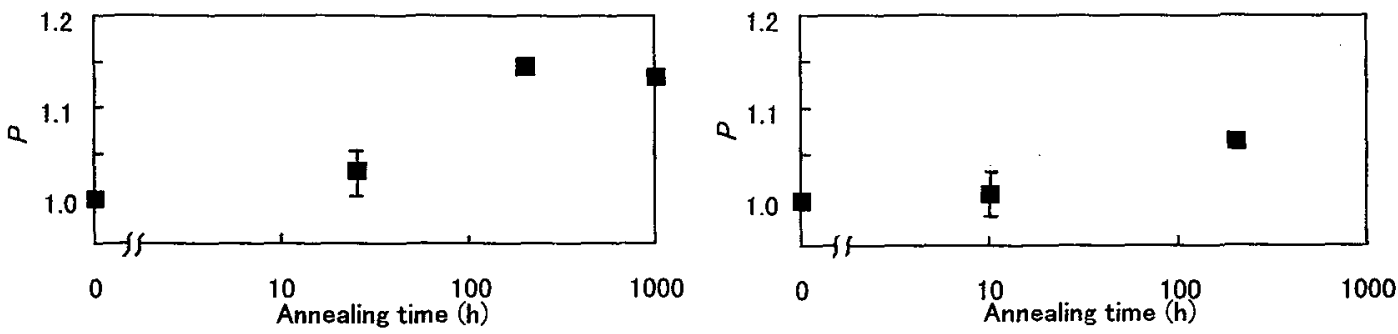

Figure 3. Relative $P$ defined by $\mathrm{eq}\left(\mathrm{I}\right.$ ) as a function of annealing time; (a) $\mathrm{Ni}_{0.75} \mathrm{Mn}_{0.25}$ and (b) $\mathrm{Ni}_{0.80} \mathrm{Mn}_{0.20}$.

\section{CONCLUSION}

We propose a simple method to estimate the degree of the short range order in NiMn alloy from EXAFS. The relation of the short-range order between $\mathrm{Ni}_{0.75} \mathrm{Mn}_{0.25}$ and $\mathrm{Ni}_{0.80} \mathrm{Mn}_{0.20}$ coincides with that of the saturation magnetization. The complicated behavior of the peak intensities of $\mathrm{FT}$ in $\mathrm{Ni}_{0.80} \mathrm{Mn}_{0.20}$ could result from a distortion of the local structure.

\section{References}

[1] Okazaki T., Jpn. J. Appl. Phys., 34 (1995) 1537-1541.

[2] Sakane H., Miyanaga T., Watanabe I., Matsubayashi N., Ikeda S. and Yokoyama Y., Jpn. J. Appl. Phys., 32 (1993)4641-4647.

[3] Cable J.W. and Tsunoda Y., Phys. Rev. B, 50 (1994) 9200-9207. 